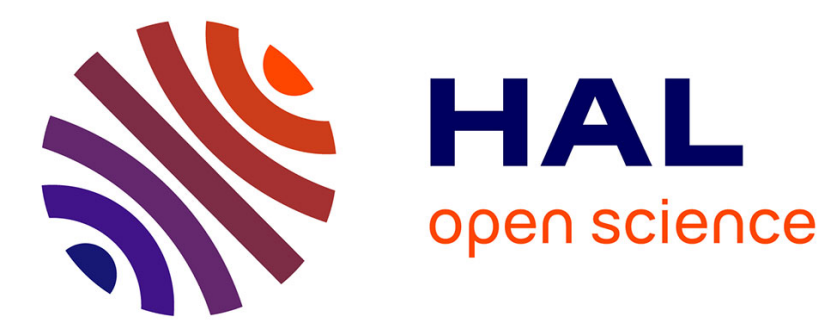

\title{
Development of a Submerged Membrane Bioreactor simulator: a useful tool for teaching its functioning
} Yusmel González Hernández, Ulises Javier Jáuregui Haza, Claire Albasi, Marion Alliet

\section{- To cite this version:}

Yusmel González Hernández, Ulises Javier Jáuregui Haza, Claire Albasi, Marion Alliet. Development of a Submerged Membrane Bioreactor simulator: a useful tool for teaching its functioning. Education for Chemical Engineers, 2014, vol. 9, pp. e32-e41. 10.1016/j.ece.2014.03.001 . hal-01069368

\section{HAL Id: hal-01069368 https://hal.science/hal-01069368}

Submitted on 29 Sep 2014

HAL is a multi-disciplinary open access archive for the deposit and dissemination of scientific research documents, whether they are published or not. The documents may come from teaching and research institutions in France or abroad, or from public or private research centers.
L'archive ouverte pluridisciplinaire HAL, est destinée au dépôt et à la diffusion de documents scientifiques de niveau recherche, publiés ou non, émanant des établissements d'enseignement et de recherche français ou étrangers, des laboratoires publics ou privés. 


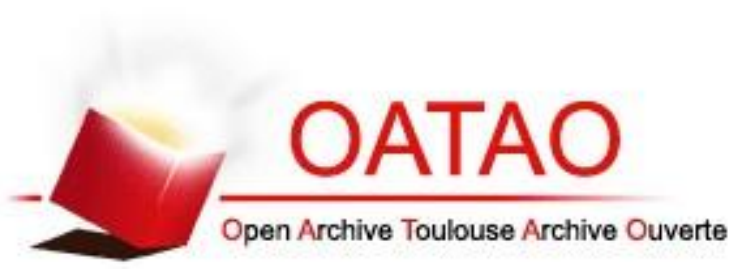

\section{Open Archive Toulouse Archive Ouverte (OATAO)}

OATAO is an open access repository that collects the work of Toulouse researchers and makes it freely available over the web where possible.

This is an author-deposited version published in: http://oatao.univ-toulouse.fr/ Eprints ID: 11427

Identification number: DOI : 10.1016/j.ece.2014.03.001

Official URL: http://dx.doi.org/10.1016/j.ece.2014.03.001

\section{To cite this version:}

González Hernández, Yusmel and Jáuregui Haza, Ulises Javier and Albasi, Claire and Alliet-Gaubert, Marion Development of a Submerged Membrane Bioreactor simulator: a useful tool for teaching its functioning. (2014) Education for Chemical Engineers, vol. 9 ( $\mathrm{n}^{\circ} 2$ ). pp. e32-e41. ISSN 1749-7728

Any correspondence concerning this service should be sent to the repository administrator: staff-oatao@inp-toulouse.fr 


\title{
Development of a Submerged Membrane Bioreactor simulator: a useful tool for teaching its functioning
}

\author{
Yusmel González Hernández ${ }^{a}$, Ulises Javier Jáuregui Haza ${ }^{a}$, \\ Claire Albasi ${ }^{b, c}$, Marion Alliet ${ }^{b, c, *}$ \\ a Instituto Superior de Tecnologías y Ciencias Aplicadas (InSTEC), Cuba \\ ${ }^{\mathrm{b}}$ Université de Toulouse, INPT, UPS, LGC, 4, Allée Emile Monso, BP 84234, F-31432 Toulouse Cedex 4, France \\ c CNRS, Laboratoire de Génie Chimique, BP 84234, F-31432 Toulouse Cedex 4, France
}

\begin{abstract}
A B S T R A C T
Among the technologies used to treat wastewater, the Submerged Membrane Bioreactor (SMBR) has excellent prospects because of the possibility it provides for water reuse. In this work, an SMBR computer simulator is developed. A mathematical model was implemented, which integrated the biological degradation process using activated sludges with the physical separation process using membranes. The simulator functioning was validated with experimental results and its use in teaching was evaluated through the development of a simulated laboratory running for three and a half hours. This gave access to trends and orders of magnitude that would take more than fifteen months to obtain with real experiments. It was successfully used and accepted by the students.
\end{abstract}

Keywords: Improving classroom teaching; Interactive learning environments; Simulations; Submerged Membrane Bioreactor

\section{Introduction}

Fresh water is becoming known as the "blue gold" of the 21st century. It is a natural resource already in short supply and it will become even scarcer with increased urbanization and population, climate change, and industrial pollution, making it humanity's most precious resource and one of the major environmental issues of this century (Buzatu and Lavric, 2011). For this reason, many governments today are devoting considerable resources and efforts to the development of new technologies for wastewater treatment and the decontamination of contaminated sources. An example of these technologies is the Submerged Membrane Bioreactor (SMBR).

The SMBR can be defined as a system that combines biological degradation of wastewater effluents with membrane filtration (Cicek et al., 1999). For many years, these systems have shown their effectiveness in the treatment of municipal and industrial wastewater (Jimenez et al., 2010; Santos et al., 2011). In the last two decades, SMBR technology has grown exponentially due to its advantages over conventional wastewater treatment processes, such as reduced environmental impact, improved effluent quality and better process control (Buer and Cumin, 2010; Drews, 2010). The major potential advantage of this technology is found in the field of water reuse. This is because the SMBR can use ultrafiltration membranes and thus retain bacteria, some viruses and many organic and inorganic components that are often found in the effluent from conventional biological treatments (Lobos et al., 2007; De Luca et al., 2013).

Therefore, the effluent of an SMBR may be suitable for direct reuse or water supply for a reverse osmosis process. That is one of the reasons why research in the SMBR field is increasing continuously at present, due the commercial and scientific interest that it has aroused (Stephenson et al., 2000; Van Nieuwenhuijzen et al., 2008). Nevertheless, the effective application of membrane bioreactors (MBRs) is limited by

\footnotetext{
* Corresponding author at: Université de Toulouse, INPT, UPS, LGC, 4, Allée Emile Monso, BP 84234, F-31432 Toulouse Cedex 4, France. Tel.: +3305343236 30; fax: +330534323700.

E-mail address: marion.alliet@ensiacet.fr (M. Alliet).
} 


\begin{tabular}{|c|c|}
\hline \multicolumn{2}{|c|}{ Nomenclature } \\
\hline A & membrane area $\left(\mathrm{m}^{2}\right)$ \\
\hline $\mathrm{C}$ & sludge concentration $\left(\mathrm{kg} / \mathrm{m}^{3}\right)$ \\
\hline$C_{d}$ & coefficient of drag and lifting forces \\
\hline$d_{p}$ & particle size $(\mathrm{m})$ \\
\hline$F_{1}$ & lifting force \\
\hline$F_{a}$ & suction force \\
\hline G & $\begin{array}{l}\text { apparent shear intensity of the fluid turbulence } \\
\left(\mathrm{s}^{-1}\right)\end{array}$ \\
\hline$g$ & gravitational constant $\left(\mathrm{m} / \mathrm{s}^{2}\right)$ \\
\hline$G_{i}$ & $\begin{array}{l}\text { apparent shear intensity of the fluid turbulence } \\
\text { on the ith section of the membrane surface }\left(\mathrm{s}^{-1}\right)\end{array}$ \\
\hline J & overall flux $\left(\mathrm{m}^{3} / \mathrm{m}^{2} \mathrm{~s}\right)$ \\
\hline$J_{i}$ & $\begin{array}{l}\text { local filtration flux through the ith membrane } \\
\text { section }\left(\mathrm{m}^{3} /\left(\mathrm{m}^{2} \text { day }\right)\right)\end{array}$ \\
\hline$M_{t d}$ & $\begin{array}{l}\text { mass of sludge in the dynamic sludge film cake } \\
\text { adhering to the membrane surface }\left(\mathrm{kg} / \mathrm{m}^{2}\right)\end{array}$ \\
\hline$M_{t f(i)}$ & $\begin{array}{l}\text { mass of sludge in the stable sludge cake } \\
\text { attached to the ith membrane section }\left(\mathrm{kg} / \mathrm{m}^{2}\right)\end{array}$ \\
\hline$M_{t d(i)}$ & $\begin{array}{l}\text { mass of sludge in the dynamic sludge film cake } \\
\text { in the ith membrane section }\left(\mathrm{kg} / \mathrm{m}^{2}\right)\end{array}$ \\
\hline$n$ & $\begin{array}{l}\text { total number of sections in the membrane sur- } \\
\text { face area }\end{array}$ \\
\hline$q_{a}$ & aeration intensity $\left(\mathrm{L} \mathrm{m}^{-2} \mathrm{~s}^{-1}\right)$ \\
\hline $\mathrm{Q}_{B G}$ & coarse bubble flow (L/s) \\
\hline$R_{m}$ & intrinsic resistance of the membrane $\left(\mathrm{m}^{-1}\right)$ \\
\hline$R_{p}$ & pore fouling resistance $\left(\mathrm{m}^{-1}\right)$ \\
\hline$r_{p}$ & $\begin{array}{l}\text { specific pore fouling resistance in terms of fil- } \\
\text { trate volume }\left(\mathrm{m}^{-2}\right)\end{array}$ \\
\hline$R_{T}$ & overall filtration resistance $\left(\mathrm{m}^{-1}\right)$ \\
\hline$r_{\text {td }}$ & $\begin{array}{l}\text { specific filtration resistance of dynamic sludge } \\
\text { film }(\mathrm{m} / \mathrm{kg})\end{array}$ \\
\hline$R_{t d}$ & resistance of dynamic sludge film $\left(\mathrm{m}^{-1}\right)$ \\
\hline $\mathrm{R}_{\mathrm{tf}}$ & resistance of stable sludge cake layer $\left(\mathrm{m}^{-1}\right)$ \\
\hline$r_{\mathrm{tf}}$ & $\begin{array}{l}\text { specific filtration resistance of sludge cake layer } \\
(\mathrm{m} / \mathrm{kg})\end{array}$ \\
\hline $\mathrm{R}_{\mathrm{TS}(\mathrm{i})}$ & $\begin{array}{l}\text { filtration resistance for the ith membrane sec- } \\
\text { tion }\left(\mathrm{m}^{-1}\right)\end{array}$ \\
\hline$S_{i}$ & a section of the membrane surface area \\
\hline$S_{I}$ & $\begin{array}{l}\text { concentration of soluble undegradable organics } \\
\left(\mathrm{gCOD} / \mathrm{m}^{3}\right)\end{array}$ \\
\hline SMBR & Submerged Membrane Bioreactor \\
\hline SMP & soluble microbial products \\
\hline $\mathrm{S}_{\mathrm{O}_{2}}$ & concentration of dissolved oxygen $\left(\mathrm{g} / \mathrm{m}^{3}\right)$ \\
\hline SRT & sludge retention time (days) \\
\hline $\mathrm{S}_{\mathrm{S}}$ & $\begin{array}{l}\text { concentration of easily biodegradable sub- } \\
\text { strates }\left(\mathrm{gCOD} / \mathrm{m}^{3}\right)\end{array}$ \\
\hline$S_{S M P}$ & $\begin{array}{l}\text { concentration of soluble microbial products } \\
\left(\mathrm{gCOD} / \mathrm{m}^{3}\right)\end{array}$ \\
\hline$t$ & time $(\mathrm{s})$ \\
\hline$t_{a B G}$ & time of coarse bubble aeration (min) \\
\hline$t_{f}$ & filtration time (min) \\
\hline TMP & trans-membrane pressure $(\mathrm{Pa})$ \\
\hline$t_{p a B G}$ & time without coarse bubble aeration (min) \\
\hline$t_{p f}$ & relaxation time (min) \\
\hline $\mathrm{t}_{\mathrm{STOP}}$ & time to simulate (days) \\
\hline V & bioreactor volume $\left(\mathrm{m}^{3}\right)$ \\
\hline$V_{f}$ & $\begin{array}{l}\text { water production within a filtration period of } \\
\text { an operation cycle }\left(\mathrm{m}^{3} / \mathrm{m}^{2}\right)\end{array}$ \\
\hline$X_{H}$ & $\begin{array}{l}\text { concentration of ordinary heterotrophic orga- } \\
\text { nisms }\left(\mathrm{gCOD} / \mathrm{m}^{3}\right)\end{array}$ \\
\hline
\end{tabular}

\begin{tabular}{|c|c|}
\hline$X_{I}$ & $\begin{array}{l}\text { concentration of particulate undegradable } \\
\text { organics }\left(\mathrm{gCOD} / \mathrm{m}^{3}\right)\end{array}$ \\
\hline$X_{S}$ & $\begin{array}{l}\text { concentration of slowly biodegradable sub- } \\
\text { strates }\left(\mathrm{gCOD} / \mathrm{m}^{3}\right)\end{array}$ \\
\hline $\mathrm{X}_{\mathrm{TSS}}$ & $\begin{array}{l}\text { concentration of total suspended solids } \\
\left(\mathrm{gTSS} / \mathrm{m}^{3}\right)\end{array}$ \\
\hline$\alpha$ & stickiness of the biomass particles \\
\hline$\beta$ & $\begin{array}{l}\text { erosion rate coefficient of the dynamic sludge } \\
\text { film }\end{array}$ \\
\hline$\Delta t$ & time step $(\mathrm{s})$ \\
\hline$\gamma$ & $\begin{array}{l}\text { compression coefficient for the dynamic sludge } \\
\text { film }\left(\mathrm{kg} \mathrm{m}^{-3} \mathrm{~s}^{-1}\right)\end{array}$ \\
\hline$\varepsilon_{a}$ & $\begin{array}{l}\text { fraction of the membrane surface area (or dis- } \\
\text { tance ratio to the bottom of the membrane } \\
\text { module) where the shear intensity is increasing }\end{array}$ \\
\hline$\varepsilon$ & $\begin{array}{l}\text { fraction of the membrane surface area (or dis- } \\
\text { tance ratio to the bottom of the membrane } \\
\text { module) }\end{array}$ \\
\hline$\theta_{f}$ & filtration time in an operation cycle (min) \\
\hline$\rho_{\mathrm{S}}$ & density of sludge suspension $\left(\mathrm{kg} / \mathrm{m}^{3}\right)$ \\
\hline$\psi$ & $\begin{array}{l}\text { reduction index of cake compression coeffi- } \\
\text { cient }\end{array}$ \\
\hline$\mu_{\mathrm{s}}$ & viscosity of sludge suspension (Pa s) \\
\hline
\end{tabular}

membrane fouling and the associated cost and energy burdens (Menniti and Morgenroth, 2010). At the same time, experimentation in these types of installations is very expensive and time consuming.

On the other hand, it is necessary to take all the elements mentioned above into account in the training of engineers and of the staff that will operate the SMBR. It is essential to develop tools that can help in the learning process, both at universities and at operator training centres. The development of simulators is a necessity since they constitute a platform to enhance virtual laboratories (Corter et al., 2011). Virtual laboratories can provide a dynamic Problem-Based Learning experience where students engage in an authentic, industrially situated task. They simulate what expert engineers do in practice, and are very different in character from the physical laboratory at university (Koretsky et al., 2011). Another advantage of a simulator is its value in the training process from the research point of view: to help to solve problems that are as yet unsolved. Simulators are also an important support for the study of process optimization.

The use of simulated experiments can considerably reduce the cost of a laboratory course, increase the number of experiments in the learning process and enable experiments to be carried out that would otherwise involve working with dangerous materials and/or in dangerous conditions (Skorzinski et al., 2009). For all these reasons, the mathematical modelling of an SMBR and the development of a simulator of this process provides an alternative that can solve many problems. The objective of this work is to develop a computer simulator of an SMBR and to show its potential in teaching how such processes work.

\section{Materials and methods}

A computer simulator consists of three main parts: the mathematical model, the numerical solution method and the graphical interface. The integrated model proposed by 


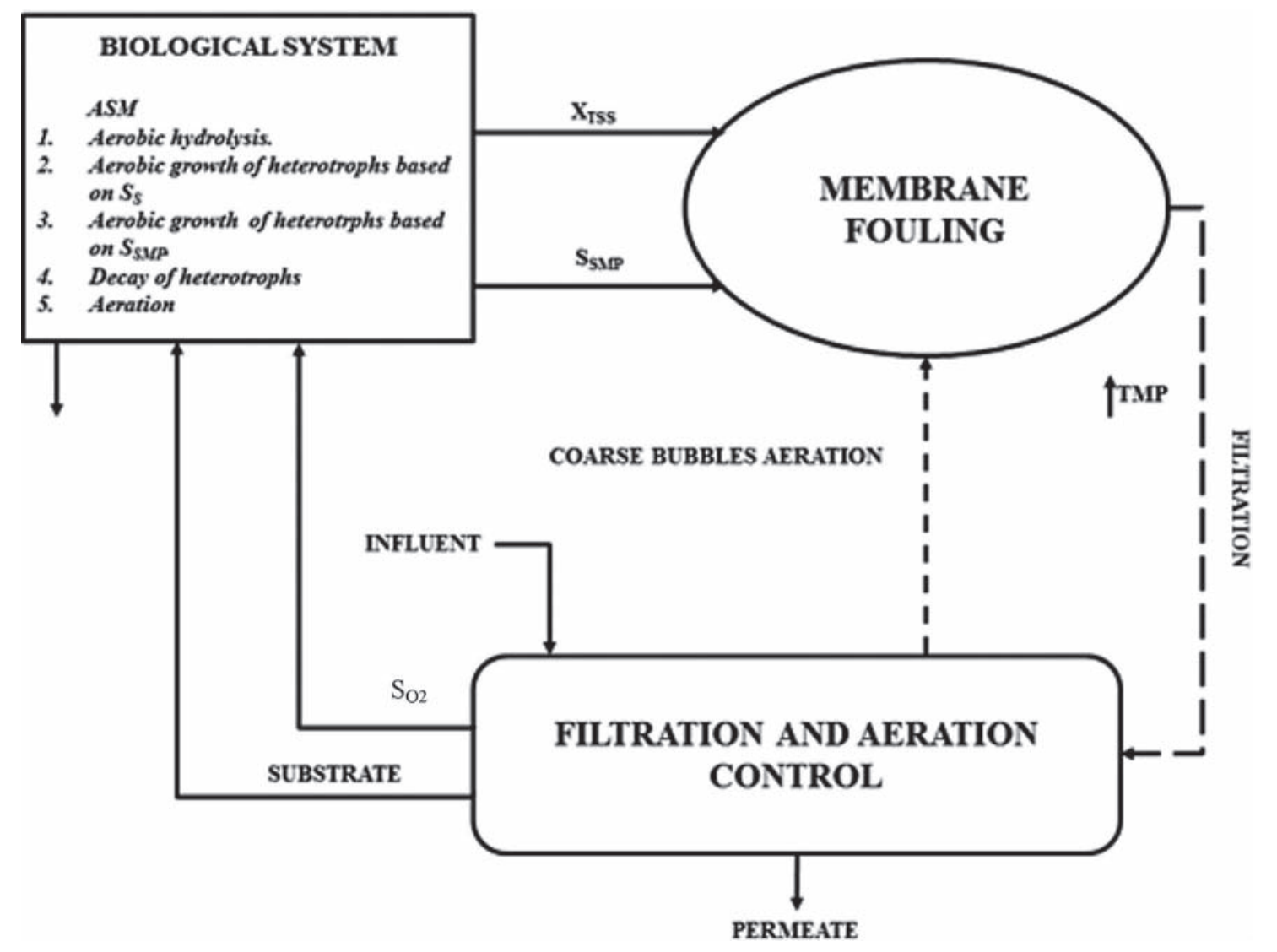

Fig. 1 - Conceptual scheme of the integrated model proposed by Zarragoitia et al. (2008).

Zarragoitia et al. (2008) was used to build the SMBR simulator. The model was implemented using the Pascal programming language. The differential equations that appear in the model were solved using the fourth-order Runge Kutta numerical method.

Finally, the simulator graphical interface was developed. Designing educational software interfaces is a complex task, given its strong domain dependency and multidisciplinary nature. It requires the teachers' knowledge and pedagogical beliefs to be incorporated into the interface, posing a challenge to both teachers and designers as they have to act as partners from the earliest phases of the process, sharing their knowledge (Perry and Schnaid, 2012). In the present case, the simulator graphical interface was built using the facilities provided by Delphi 2009 for object-oriented programming, in order to achieve a friendly graphical interface enabling the assignation and manipulation of different operating parameters, as well as observation of how the variables of interest behave over time.

\subsection{Mathematical model and its implementation}

The mathematical model proposed by Zarragoitia et al. (2008) integrates the biological degradation process by activated sludges with the physical separation process using membranes.

In order to facilitate the evaluation of the model, the selection of equations and biological processes considered during modelling was linked to the characteristics of the experimental reactor and its operating conditions. However, the final structure of the model offers the possibility of adding other process rates and stoichiometries. The conceptual scheme of the model developed is shown in Fig. 1. It gives the main relations operating during simulation and also the information flow established among the different parts of the model during calculation. The model is divided into three sections, the first considers the biological behaviour (stoichiometry and kinetics), the second is related to membrane fouling evolution and the behaviour of all filtration resistances, and the last consists of a set of periodic equations that represent the process associated with coarse bubble aeration, feeding and discontinuous filtration.

To simulate the activated sludge process, a modified model was established considering the formation-degradation kinetics of soluble microbial products proposed in the modification of ASMl developed by Lu et al. (2001), but adapting these equations to a strictly aerobic SMBR. The biological model consists of a system of differential equations obtained from the Peterson matrix (Zarragoitia et al., 2008).

On the other hand, in the physical separation model, the main process is the mass attached to the membrane surface. This process is described by Eq. (1):

$\frac{d M_{t d}}{d t}=\frac{24 C J^{2}}{24 J+C_{d} d_{p} G}-\frac{\beta(1-\alpha) G M_{t d}^{2}}{\gamma V_{f} t+M_{t d}}$

The first term of Eq. (1) represents the net mass deposited on the membrane surface due to the equilibrium between the suction and lifting forces (Fig. 2), while the second term represents the mass removed by the shear forces caused by the coarse bubble aeration (Li and Wang, 2006).

Shear forces are not uniformly distributed over the membrane surface. When modelling the deposition of sludge on the membrane surface, in the case where the membrane module resembles to a cylindrical object, the variation of $G$ values 


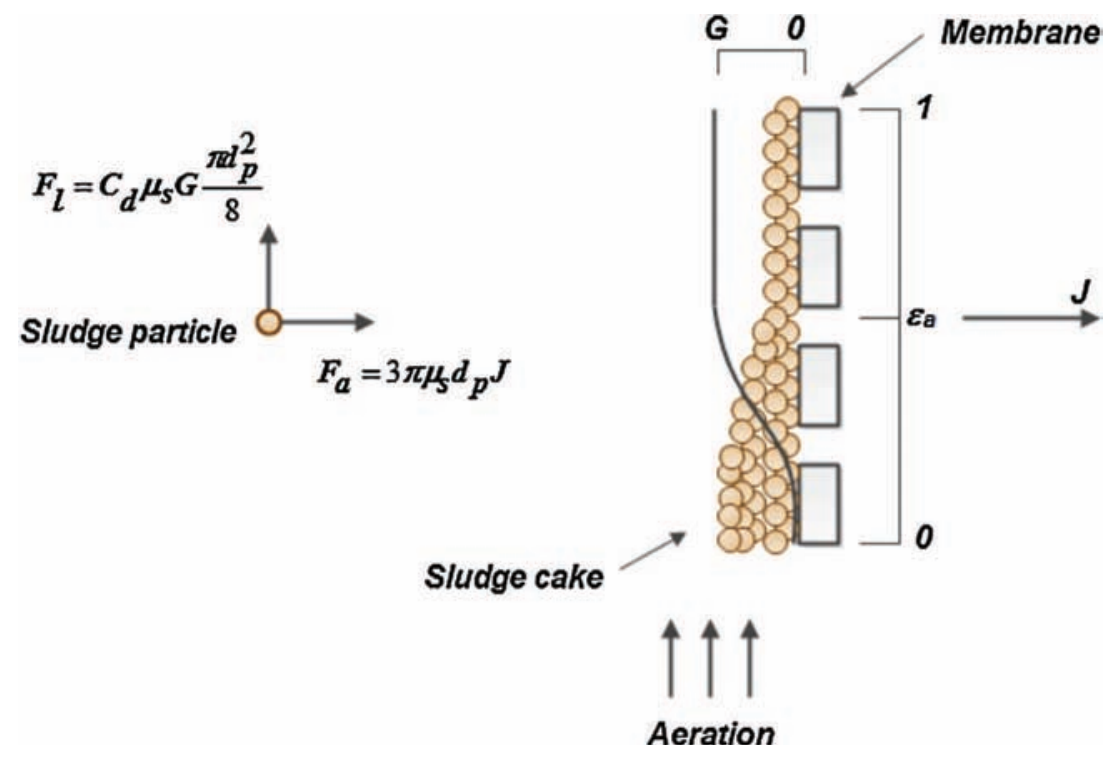

Fig. 2 - Modelling the membrane fouling process.

in the vicinity of the membrane module can be estimated as follows:

- at the bottom of the membrane module, $G$ value is assumed the smallest possible value, which is one-tenth of its maximum value,

- for distance ratios to the bottom higher than $\varepsilon_{a}, G$ value is assumed to take its maximum value,

- between the two, sinusoidal growth is assumed (Fig. 2).

Therefore, Eqs. (2) and (3) are used to calculate the $G_{i}$ values. These equations must be modified for the case of modules with different geometry or different aeration systems, e.g. with air nozzles located at multiple heights of the membrane module, which are not frequent due the structural complexities and changes that the hydrodynamics of the system introduces (Zarragoitia et al., 2008).

$G(\varepsilon)=\left\{\begin{array}{l}{\left[0.1+0.45\left(1+\sin \frac{\left(2 \varepsilon-\varepsilon_{a}\right) \pi}{2 \varepsilon_{a}}\right)\right] \sqrt{\frac{\rho_{\mathrm{s}} g q_{a}}{\mu_{\mathrm{s}}}}, \varepsilon<\varepsilon_{a}} \\ \sqrt{\frac{\rho_{\mathrm{s}} g q_{a}}{\mu_{\mathrm{s}}}}, \varepsilon \geq \varepsilon_{a}\end{array}\right\}$

where

$q_{a}=\frac{\mathrm{Q}_{\mathrm{BG}}}{\mathrm{A}}$

For the modelling of membrane fouling, the membrane surface was divided into sections of equal area $\left(S_{i}\right)$. It was considered that each area $S_{i}$ was traversed by a flow of equal magnitude, which was calculated by the following equation:

$J_{i}=\frac{J}{n}$

Eq. (4) was adapted so as to calculate the mass of sludge deposited in the ith section of the membrane surface. Li and Wang, (2006) found that 128 sections of equal area $\left(S_{i}\right)$, guaranteed a good approximation to system behaviour.

Also, the overall flux (J) in Eq. (1) is replaced by the local filtration flux through the ith membrane section $\left(J_{i}\right)$ and the apparent shear intensity of the fluid turbulence $(G)$ is replaced by the actual shear intensity on the ith section of the membrane surface $\left(G_{i}\right)$. Hence, with these transformations Eq. (1) can be expressed as:

$\frac{d M_{t d(i)}}{d t}=\frac{24 C J_{i}^{2}}{24 J_{i}+C_{d} d_{p} G_{i}}-\frac{\beta(1-\alpha) G_{i} M_{t d(i)}^{2}}{\gamma V_{f(i)} t+M_{t d(i)}}$

This type of installation works in periodic cycles of filtration and cleaning by coarse bubble aeration so, when the system is filtering, the mass attached to the membrane surface is calculated using Eq. (5), but when the system is not filtering, the only process that can occur is removal of the sludge from the membrane surface. In this case Eq. (6) is used to calculate the mass attached to the membrane surface, which is a modification of Eq. (5).

$\frac{d M_{t d(i)}}{d t}=-\frac{\beta(1-\alpha) G_{i} M_{t d(i)}^{2}}{\psi \gamma V_{f(i)} \theta_{f}+M_{t d(i)}}$

For each new time step: $M_{t f(i)}(t+\Delta t)=M_{t f(i)}(t)+M_{t d(i)}(t)$.

Another parameter to be taken into account is the pore fouling resistance. Pore fouling occurs as a result of the adhesion of some sludge particles having a diameter less than or of the order of the diameter of the pores on the interior walls (Meng et al., 2009). Then, the filtration resistance for the ith membrane section is determined by the following expression:

$R_{T S(i)}=R_{m(i)}+R_{p(i)}+R_{t d(i)}+R_{t f(i)}$

where

$R_{m(i)}=$ const

$R_{p(i)}=r_{p} \sum_{k=1}^{m} J_{i} \theta_{f(k)}$

$R_{\mathrm{td}(\mathrm{i})}=r_{\mathrm{td}} \mathrm{M}_{\mathrm{td}(\mathrm{i})}$

$R_{t f(i)}=r_{t f} M_{t f(i)}$ 


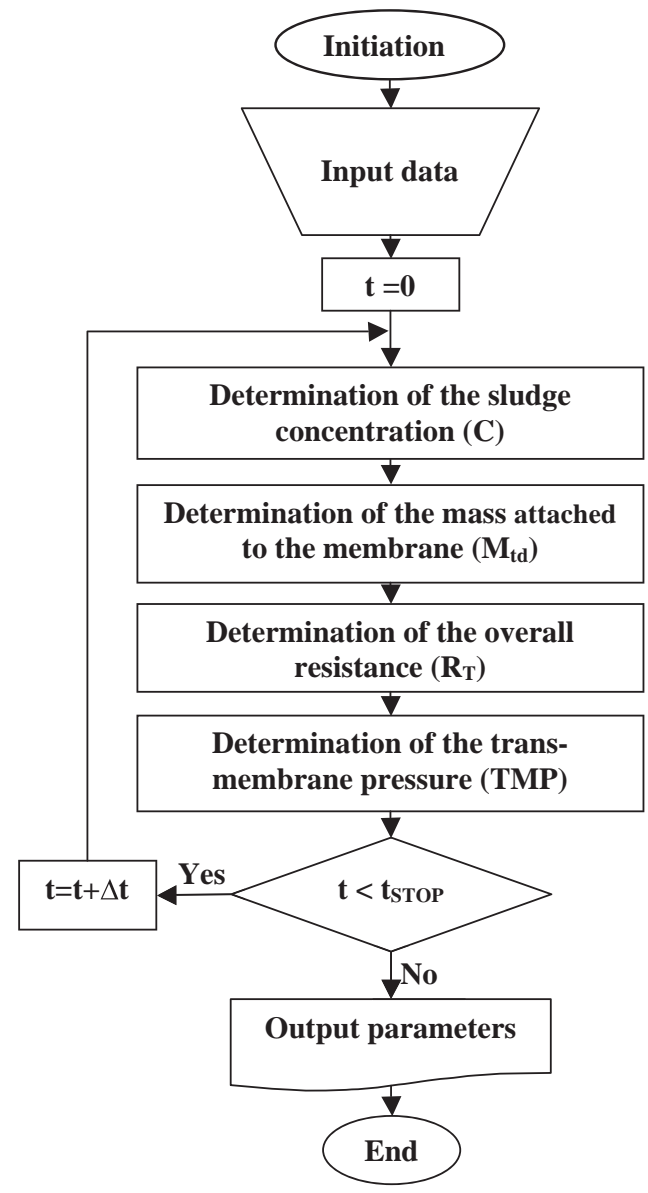

Fig. 3 - General algorithm for the implementation of the mathematical model.

Once the value of the filtration resistance for the ith membrane section has been determined, the value of the overall resistance can be calculated by means of the expression (12).

$\frac{1}{R_{T}}=\sum_{i=1}^{n} \frac{S_{i}}{R_{T S(i)}}$

Finally, the value of TMP can be determined using Darcy's law (13):

$\mathrm{TMP}=\mu_{\mathrm{S}} J R_{\mathrm{T}}$

The general scheme of the algorithm for implementing the mathematical model is shown in Fig. 3.

For the calculation, the sludge concentration is determined by solving the system of differential equations for the biological system. Then, the mass of sludge attached to the membrane surface and its resistance to filtration are determined. Later, the overall resistance value is evaluated in the expression of Darcy's law so that the TMP value can be obtained. The output parameters of the simulator are shown at each $1 \mathrm{~s}$ time interval, which is the step used by the fourthorder Runge Kutta numerical method during the calculation.

Nowadays, many unit process models are available in the field of wastewater treatment. All of these models use their own notation, which causes problems for documentation, implementation and connection of different models (using different sets of state variables) (Corominas et al., 2010). For this reason, in this work, the universal notation proposed by
Corominas et al. (2010) to describe mathematical models is used.

\subsection{Evaluation of the simulator}

To demonstrate the simulator capacity to describe the performance of a real membrane bioreactor, the experimental data reported by Zarragoitia et al. (2008) were used. Tables 1-3 show the working conditions in which the experiments were conducted, the characteristics of the wastewater used and the characteristics of the activated sludge at the beginning of the experiments, respectively.

\subsection{Practical application of the simulator in chemical engineering education}

The simulator was used in chemical engineering education in December 2012 and in Decembre 2013 at the Ecole Nationale Supérieure des Ingénieurs en Arts Chimiques Et Technologiques (ENSIACET), France. The use of this software was incorporated into the syllabus of the "Water treatment" course in the fifth year of higher education corresponding to the Chemical Engineering Careers unit. The objectives of the practical activity are that the students become familiarized with a water treatment process, that they understand how the SMBR process works and that they analyze the influence of operating parameters on the functioning of the process. For this purpose practical work lasting three and a half hours in a simulated laboratory was developed. It was structured in three steps:

1. Analysis of the mathematical model implemented in the simulator in order to better understand the results obtained with the simulator.

2. Resolution of a practical problem using the simulator.

3. Writing of the report by the students, with the results and discussion of all the simulator predictions.

\subsubsection{Practical activity}

A practical exercise was developed using experimental data from a real plant (Zarragoitia et al., 2008). The exercise is described below.

An MBR pilot plant with a submerged membrane configuration is located in the town of Brax, France. This plant is fed with a volumetric flow of $0.09 \mathrm{~m}^{3}$ day $^{-1}$ of real wastewater, the characteristics of which are shown in Table 1. Specifically, a polysulfone hollow-fibre membrane module supplied by Polymen (pore size $=0.2 \mu \mathrm{m}$, surface area $=0.3 \mathrm{~m}^{2}$ ) is immersed directly in an aerobic tank with a volume of $10 \mathrm{~L}$. The sludge retention time is around 30 days. The biological reactor is aerated and stirred by a fine bubble air diffuser located at the bottom of the reactor. A second air blower, located directly at the bottom of the membrane module, produces an air flow rate of $6 \mathrm{~L} \mathrm{~m}^{-2} \mathrm{~s}^{-1}$ to generate coarse bubbles that cause strong turbulence so as to clean the surface of the membrane and thus limit membrane fouling. Membrane filtration is carried out in conventional sequential cycle mode: 9 min with filtration and $1 \mathrm{~min}$ without filtration (relaxation time). During the relaxation time, the coarse bubble aeration is on, so the membrane cleaning is carried out in a cycle mode: 1 min of coarse bubble aeration and 9 min without such aeration.

The maintenance of the system is performed when transmembrane pressure reaches its critical value, which in this case is fixed at $60 \mathrm{kPa}$. The mean temperature inside of MBR 
Table 1 - Working conditions in which the experiments were performed in the SBRM.

\begin{tabular}{lcccccccc} 
Temperature $\left({ }^{\circ} \mathrm{C}\right)$ & $q_{a}\left(\mathrm{~L} \mathrm{~m}^{-2} \mathrm{~s}^{-1}\right)$ & $t_{f}(\mathrm{~min})$ & $t_{p f}(\mathrm{~min})$ & $t_{a B G}(\mathrm{~min})$ & $t_{p a B G}(\mathrm{~min})$ & $\mathrm{SRT}(\mathrm{days})$ & $\mathrm{J}\left(\mathrm{m}^{3} /\left(\mathrm{m}^{2} \mathrm{day}\right)\right)$ \\
\hline 7.3 & 11 & 10 & 4 & 2 & 8 & 40 & 0.25 \\
\hline Source: Zarragoitia et al. (2008).
\end{tabular}

Table 2 - Characteristics of the wastewater to be treated.

\begin{tabular}{cccccccc}
$\mathrm{X}_{\mathrm{SST}}(\mathrm{mg} / \mathrm{L})$ & $\mathrm{X}_{\mathrm{S}}(\mathrm{mg} / \mathrm{L})$ & $\mathrm{X}_{\mathrm{I}}(\mathrm{mg} / \mathrm{L})$ & $\mathrm{X}_{\mathrm{H}}(\mathrm{mg} / \mathrm{L})$ & $\mathrm{S}_{\mathrm{S}}(\mathrm{mg} / \mathrm{L})$ & $\mathrm{S}_{\mathrm{I}}(\mathrm{mg} / \mathrm{L})$ & $\mathrm{S}_{\mathrm{PMS}}(\mathrm{mg} / \mathrm{L})$ & $\mathrm{S}_{\mathrm{O}_{2}}(\mathrm{mg} / \mathrm{L})$ \\
\hline 50 & 70 & 40 & 10 & 220 & 10 & 60 & 0.2 \\
\hline
\end{tabular}

Source: Zarragoitia et al. (2008).

Table 3 - Characteristics of the activated of sludge at the beginning of the experiments.

\begin{tabular}{cccccccc}
$\mathrm{X}_{\mathrm{SST}}(\mathrm{mg} / \mathrm{L})$ & $\mathrm{X}_{\mathrm{S}}(\mathrm{mg} / \mathrm{L})$ & $\mathrm{X}_{\mathrm{I}}(\mathrm{mg} / \mathrm{L})$ & $\mathrm{X}_{\mathrm{H}}(\mathrm{mg} / \mathrm{L})$ & $\mathrm{S}_{\mathrm{S}}(\mathrm{mg} / \mathrm{L})$ & $\mathrm{S}_{\mathrm{I}}(\mathrm{mg} / \mathrm{L})$ & $\mathrm{S}_{\mathrm{PMS}}(\mathrm{mg} / \mathrm{L})$ & $\mathrm{S}_{\mathrm{O}_{2}}(\mathrm{mg} / \mathrm{L})$ \\
\hline 5500 & 10 & 10 & 550 & 130 & 10 & 90 & 10 \\
\hline
\end{tabular}

Source: Zarragoitia et al. (2008).

is $20^{\circ} \mathrm{C}$ during the entire campaign. Tables $2-4$ show the data necessary for the MBR operation: the supply characteristics, the characteristics of the mixture inside the MBR and the properties of the activated sludge and cake formed on the membrane surface, respectively.

\subsubsection{Activities. Using the software}

1. Simulate the operation of the MBR over 8 days. Describe the behaviour over time of the following parameters:

- Trans-membrane pressure.

- Total suspended solids.

- Chemical oxygen demand.

- Filtered water volume.

- Soluble microbial products.

- Overall resistance to filtration.

- Dissolved oxygen.

2. Determine the time necessary for the system to reach the critical trans-membrane pressure working in the operating conditions described above.

3. What needs to be done if the system reaches the critical trans-membrane pressure?

4. In order to understand the influence of the following variables on the trans-membrane pressure, perform a sensitivity analysis in the indicated ranges:

- Filtration flux ( $\pm 5 \%$ of established value).

- Specific filtration resistance of the sludge cake layer $( \pm 5 \%$ of established value).

Discuss the results of the sensitivity analysis.

\section{Table 4 - Properties of the activated sludge and cake} formed on the membrane surface.

\begin{tabular}{ll} 
Parameters & Value \\
\hline Erosion rate coefficient of the dynamic sludge film & $3.5 \times 10^{-4}$ \\
Stickiness of the biomass particles & 0.7 \\
Particle size $(\mathrm{m})$ & $1 \times 10^{-4}$ \\
$\begin{array}{l}\text { Specific filtration resistance of the dynamic sludge } \\
\text { film }(\mathrm{m} / \mathrm{kg})\end{array}$ & $1 \times 10^{15}$ \\
$\begin{array}{l}\text { Specific filtration resistance of the sludge cake layer } \\
(\mathrm{m} / \mathrm{kg})\end{array}$ & $1 \times 10^{15}$ \\
$\begin{array}{l}\text { Compression coefficient for the dynamic sludge film } \\
\left(\mathrm{kg} \mathrm{m} \mathrm{s}^{-1}\right)\end{array}$ & $2.5 \times 10^{-5}$ \\
$\begin{array}{l}\text { Coefficient of the drag and lifting force } \\
\text { Reduction index of the cake compression coefficient }\end{array}$ & 0.4 \\
\hline
\end{tabular}

5. For the purpose of determining the best operating conditions, plot the time necessary for the system to reach the critical trans-membrane pressure versus the following variables (maintaining the rest of the operating conditions constant):

- Filtration frequency (Filtration time/Relaxation time $=9: 1,7: 3,5: 5,3: 7$ and 1:9)

- Aeration intensity $\left(3,6,9,12\right.$ and $\left.15 \mathrm{~L} \mathrm{~m}^{-2} \mathrm{~s}^{-1}\right)$

Discuss the results obtained.

\subsubsection{Anonymous questionnaire}

At the end of the practical activity, the students were asked to fill in an anonymous questionnaire giving their opinion about the simulated laboratory (Table 5).

\section{Results and discussion}

\subsection{Description and operation of the simulator}

For teaching use, the SBRM computer simulator developed should be user friendly and provide an easily accessible introduction to the subject. Since other uses are advanced training and research, many parameters should be easily modifiable.

The simulator shows a general standard scheme of the SMBR, which allows the main structural components of the system to be apprehended, so that the user can gain a better understanding of the installation performance and thus a better understanding of the processes that are involved in these types of installations (Fig. 4).

The simulator allows the user to study of the influence of the 35 model input variables (those presented in Tables 1-4, bioreactor volume, membrane surface and time to be simulated) on 16 output parameters, which can be displayed graphically or numerically. These output parameters are:

1. Trans-membrane pressure.

2. Resistance of the stable sludge cake layer.

3. Resistance of the dynamic sludge film.

4. Pore fouling resistance.

5. Overall resistance.

6. Chemical oxygen demand.

7. Dissolved oxygen.

8. Easily biodegradable substrates. 
Table 5 - Questions presented to the students.

\begin{tabular}{|c|c|c|c|c|c|c|}
\hline No & Questions & Strongly agree & Agree & Disagree & Strongly disagree & I don't know \\
\hline 1 & This laboratory is interesting & $\square$ & $\square$ & $\square$ & $\square$ & $\square$ \\
\hline 2 & $\begin{array}{l}\text { This laboratory helped me to represent } \\
\text { the real functioning of a membrane } \\
\text { bioreactor }\end{array}$ & $\square$ & $\square$ & $\square$ & $\square$ & $\square$ \\
\hline 3 & $\begin{array}{l}\text { With this exercise, I have a better } \\
\text { understanding of the influence of the } \\
\text { membrane bioreactor functioning } \\
\text { parameters on the process performance }\end{array}$ & $\square$ & $\square$ & $\square$ & $\square$ & $\square$ \\
\hline 4 & $\begin{array}{l}\text { I was able to understand the functioning } \\
\text { of the simulator by myself }\end{array}$ & $\square$ & $\square$ & $\square$ & $\square$ & $\square$ \\
\hline 5 & $\begin{array}{l}\text { The participation of the teacher helped } \\
\text { me understand the functioning of the } \\
\text { simulator better }\end{array}$ & $\square$ & $\square$ & $\square$ & $\square$ & $\square$ \\
\hline 6 & $\begin{array}{l}\text { The problem presented to me was clearly } \\
\text { defined }\end{array}$ & $\square$ & $\square$ & $\square$ & $\square$ & $\square$ \\
\hline 7 & $\begin{array}{l}\text { This activity enabled me to understand } \\
\text { why a computer simulators is an useful } \\
\text { tool in chemical engineering }\end{array}$ & $\square$ & $\square$ & $\square$ & $\square$ & $\square$ \\
\hline 8 & $\begin{array}{l}\text { This laboratory is well situated in my } \\
\text { education programme }\end{array}$ & $\square$ & $\square$ & $\square$ & $\square$ & $\square$ \\
\hline 9 & $\begin{array}{l}\text { This laboratory is relevant to my } \\
\text { programme }\end{array}$ & $\square$ & $\square$ & $\square$ & $\square$ & $\square$ \\
\hline 10 & $\begin{array}{l}\text { The activity helped me to consolidate the } \\
\text { concepts exposed in the classroom }\end{array}$ & $\square$ & $\square$ & $\square$ & $\square$ & $\square$ \\
\hline
\end{tabular}

9. Soluble undegradable organics.

10. Soluble microbial products.

11. Particulate undegradable organics.

12. Slowly biodegradable substrates.

13. Ordinary heterotrophic organisms.

14. Total suspended solids.

15. Mass attached to the membrane.

16. Filtered water volume.

The simulator enables the user to select, before calculating, the time-scale over which results will be presented.
This time-scale can be seconds, minutes, hours or days. The precision of calculation does not change with the time scale selected because it is always performed in seconds.

Also, the simulator allows the numerical results to be exported to a txt file. This option may permit the user to process these results using other computational tools. Similarly, the graphical results can be saved in bmp image format. Another advantage is that each calculation can be saved in a file using bms format, an extension created for this software. Finally the simulator opens the possibility of a sensitivity analysis with respect to various parameters.

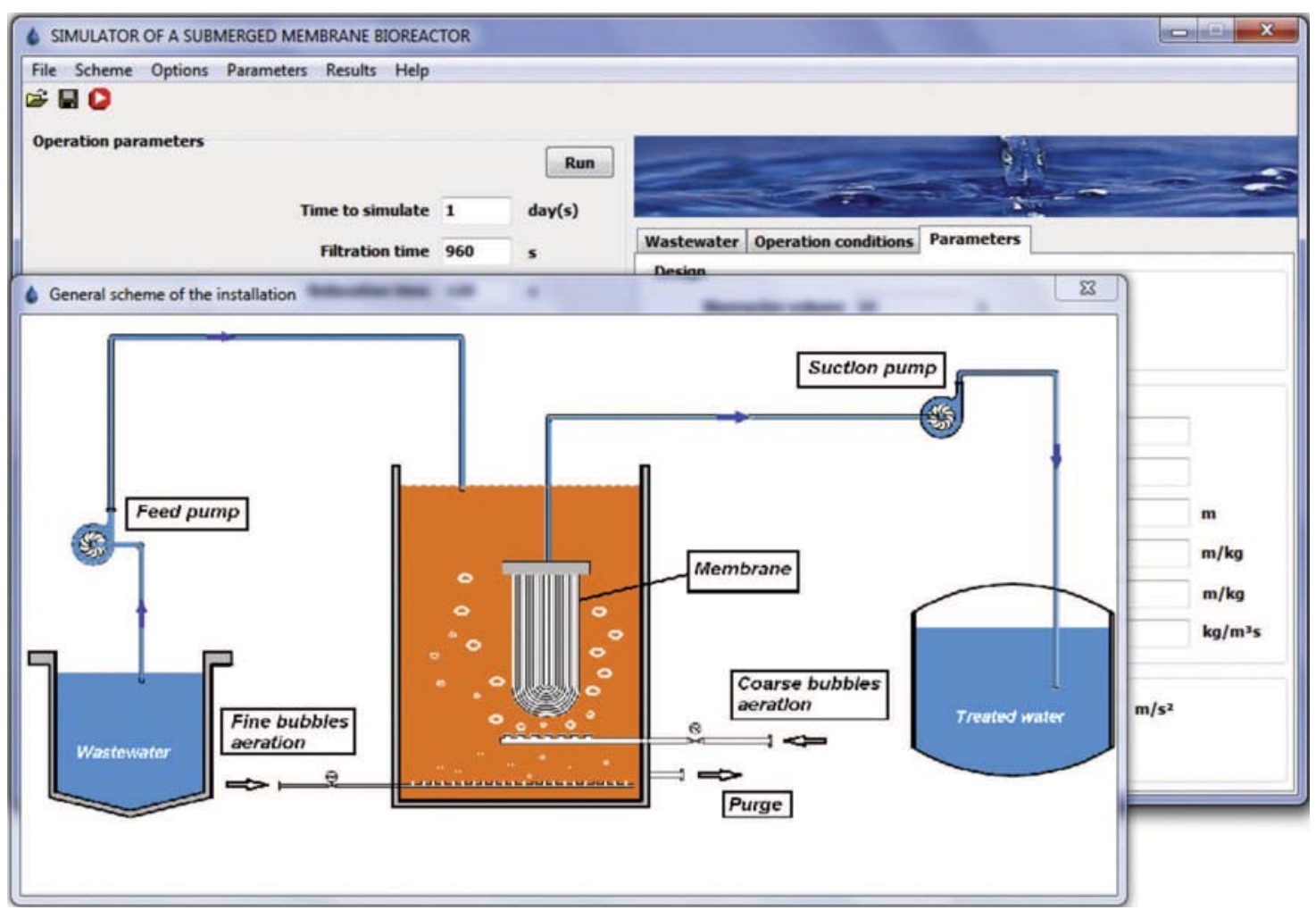

Fig. 4 - Main graphical interface of the SMBR simulator and general scheme of the installation. 

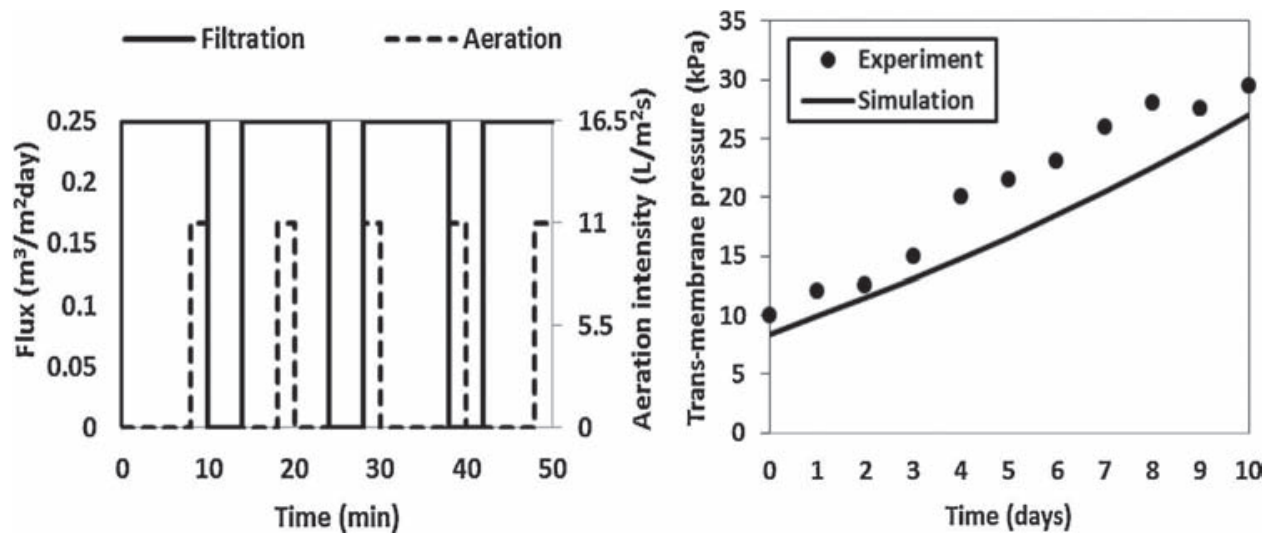

Fig. 5 - Comparison between the experimental data (points) and simulation results (line). The left-hand diagram shows the working conditions of the experiments.

\subsection{Comparison of simulator performance with experimental data}

To substantiate and justify the use of the computer simulator to study an SMBR, it is essential to know the level of approximation to which the mathematical model can reproduce SMBR operation. For this reason, the simulation results were compared with experimental data.

The parameter chosen was the trans-membrane pressure because of its importance in the operation of the SMBR (Meng et al., 2009; Fenu et al., 2010). Fig. 5 shows the experimental and calculated values of TMP. A mean relative error of estimation of $15 \%$ was obtained.

This result can be considered acceptable for predicting the behaviour of a system of such complexity because, as explained above, the simulator was built by implementing a model that combines biological degradation with the filtration process. The biological system modelling introduces a high percentage of error as the input values of biological variables correspond to the mean values measured during the experiment (Zarragoitia et al., 2008).

Even with $15 \%$ of error, the simulator already gives the trends in the evolution of physical quantities and the order of magnitude of their values, which is the information sought.

\subsection{Practical application of the simulator in chemical engineering education}

Before beginning the practical activity, the teacher gave the students a brief overview of the model implemented in the simulator as a "black box". Once the students had received the orientation information and the necessary materials, they were ready to start the proposed exercise. The instructor was at hand during the entire practical activity, and was available to clarify any points the students had doubts about. Finally, the students prepared a report with the exercise solution. When they had finished the work in the simulated laboratory, the students answered the anonymous questionnaire, which was drawn up in the aim of knowing the students' opinions about the simulated laboratory.

The evaluations of how well the objectives of this practical activity were attained were made:

- during the activity itself, by the discussion between the students and the teaching staff,

- from the reports given by the students,

- by the students' answers to the questionnaire.

\subsubsection{Considerations about the practical activity}

The practical activity was carried out successfully by the students. They showed their abilities in the use of computer programs and, in general, they managed the simulator with success. Nevertheless, there were some students who had difficulty solving this task because they did not understand the functioning of an SMBR correctly and others who had problems with the simulator language. However, with the instructor's help, they finished the proposed exercise correctly. The students' correct use of the different simulator tools and their understanding of the SMBR operation was evaluated from their analysis of the results they reported.

The reports were corrected and graded according to the French norm, which gives points out of 20, with the following appreciation: $10=$ pass, 12 = quite good, $14=$ good, $16=$ very good, $18=$ excellent, and $20=$ congratulations. The average was $13.6 / 20$ with a minimum of $12 / 20$ and a maximum of $16 / 20$, which is a rather good result. Parts 1-4 were achieved very well, with only minor mistakes. Part 5 was completed in a more variable way, mainly due to a lack of time (and to the French way of teaching, which discriminates using time).

\subsubsection{Students' opinions}

The students' responses to the questionnaire are presented in Fig. 6. A grading scale obtained by using numerical equivalents for the opinions: "Strongly agree" $=20$, "Agree" $=13.33$, "Disagree" $=6.67$, "Strongly disagree" $=0$ (in order to correspond to the French grading system, which is out of 20) has been added. For each of the statements proposed in the questionnaire, a "grade" is indicated, which was obtained by averaging the answers. To analyze these responses, the questions with the most numerous answers "Disagree" were considered as well as the ones with less good grades. The students' evaluations were very positive. This simulated laboratory aroused great interest in more than $95 \%$ of the students.

As noticed by the teaching staff during the practical activity, although some students had some difficulties in understanding the functioning of the simulator by themselves (Q4), the participation of the teacher helped them in this task (Q5).

Slightly more than $10 \%$ of the students did not agree that this laboratory was relevant to their programme and the lowest evaluation concerned the situation of this laboratory in the education programme $(\mathrm{Q} 8)$. A discussion with the students showed that an additional experimental activity may help to improve this impression. The teaching staff is thinking about a convenient and not too expensive way to include it (visit to a 


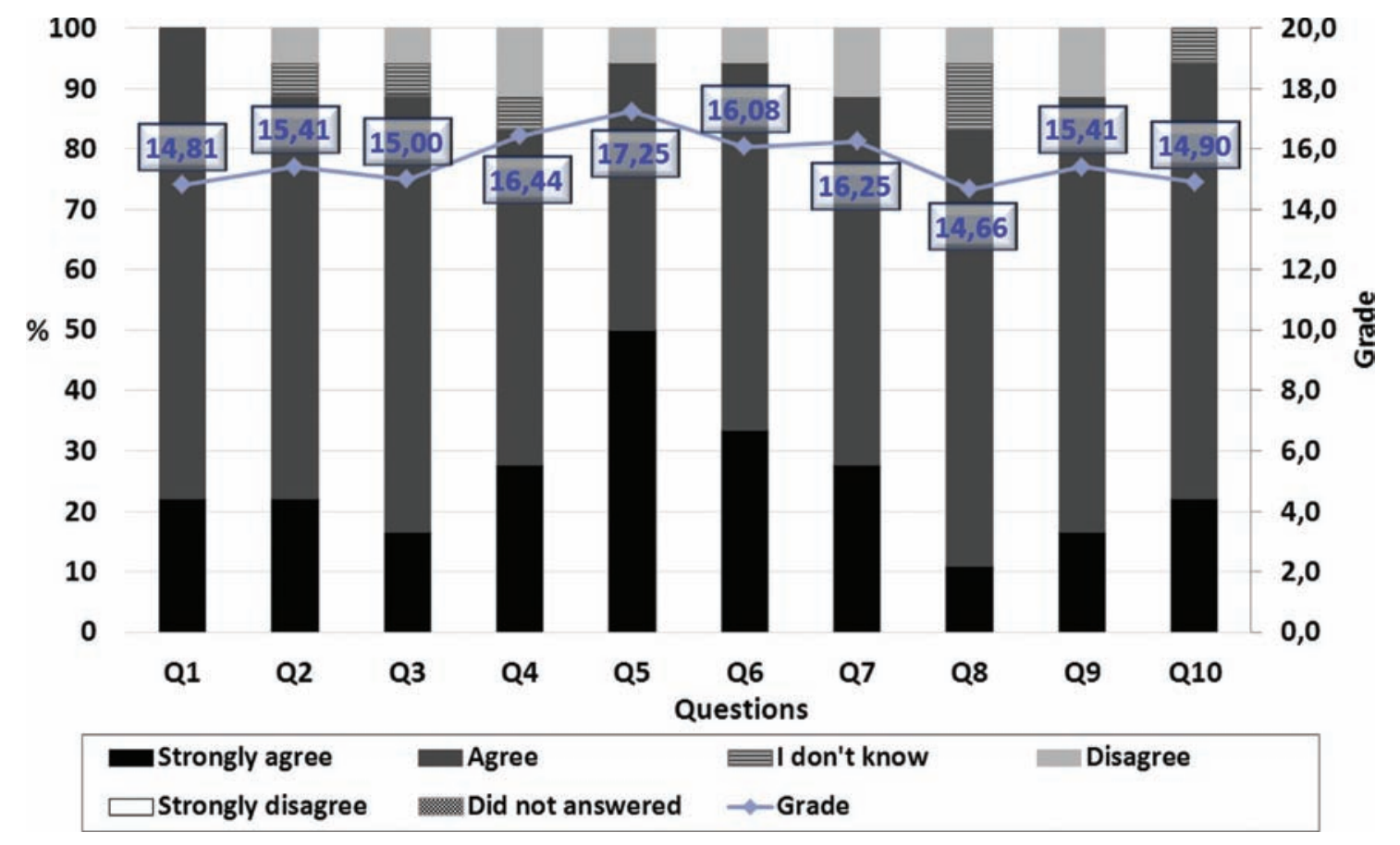

Fig. 6 - Results of the anonymous questionnaire (see Table 5).

water treatment plant, visit to a research experimental device, short experimental practical activity, etc.)

\subsection{Advantages of simulator in teaching}

Laboratory exercises, field observations and field trips are a fundamental part of many earth science and environmental science courses. Field observations and field trips can suffer from constraints of distance, time, expense, and the scale, safety, or complexity of real-world environments (Ramasundaram et al., 2005). Corter et al. (2011) state that the majority of comparative studies have concluded that simulation is a good substitute for hands-on labs in teaching course concepts and their application but some researchers have proposed that simulation might be most effective when it is integrated as a complementary part of a course involving hands-on laboratory activity.

In comparison with textbooks and lectures, a learning environment with a computer simulation has the advantages that students can systematically explore hypothetical situations, interact with a simplified version of a process or system, change the time-scale of events, and practice tasks and solve problems in a realistic environment without stress (van Berkum and de Jong, 1991).

El-Naas (2011) developed a course following the active learning approach, where students are heavily involved in class activities and they can directly assess the effect of input variables on the design parameters, allowing them to carry out "What If" or parameter sensitivity analysis. For this he used Excel and Ez-Solve in designing and analysing desalination processes. Simulations have earned a place in the classroom as robust additions to the teachers' repertoire, either as an addition to the traditional teaching methods available or as a replacement of parts of the curriculum (Rutten et al., 2012). As shown here, the SMBR computer simulator developed is able to predict the behaviour of various output parameters in the short- and long-term. It allows users to study the influence of the bioreactor initial working conditions on the behaviour of the main parameters that describe the plant performance.
It also allows the optimum SMBR operating conditions to be determined so as to increase the membrane lifespan. At the same time, it facilitates studies related to the search for the optimal design parameters of the plant and the influence of sludge properties, which will lead to better efficiency in the process of wastewater treatment. It also facilitates sensitivity studies on the most important parameters in the system, which is a fundamental aspect to be considered in future modelling work so that the major contributors to the estimation error of the model can be determined. Last but not least, it gives access to intermediate parameters that cannot be regularly measured in real conditions, such as the resistances of the stable sludge cake layer and the dynamic sludge film, or the concentration of soluble microbial products, but which contribute to a better understanding of the way the process functions (membrane fouling, COD, etc.). It is important to note that the simulator was built in a manner that makes it an invaluable tool for teaching how an SMBR works, since it allows the user to interact with the operating conditions of the bioreactor and observe the influence of these parameters on the behaviour of the main control variables of the system over time.

Computer modelling has become a helpful tool in the analysis of the performance and effectiveness of wastewater treatment systems (Korniluk et al., 2008). Nowadays, industrial firms have become very interested because computer simulations significantly lower costs compared to experimental studies (Kraft et al., 2005). The use of the SMBR simulator allows considerable saving of resources and time since, in general, performing experiments in real time on an SMBR is very expensive and time consuming. For the practical activity, we were able to place 24 students in front of their own 12 "devices". This allowed them to virtually implement several operating conditions and to analyze the consequences of this control. The user friendliness of the simulator helped in this, in a time much shorter than in the real world and at a cost compatible with the university's resources. The role of the teachers was to supply the students with all the practical procedures that are not included in the simulator, such as 
chemical cleaning or membrane replacement, and to keep the students aware of the real context of in situ experiments compared to in silico ones. In the case of the treatment plant under study, the plant needs a period of almost 20 days for the sludge mixture to become stabilized and, each time the critical value of trans-membrane pressure is reached, the system must be stopped to carry out expensive chemical cleaning or replacement of the membrane, often before the end of its lifespan (Zarragoitia et al., 2008; Kim et al., 2011). However, this study can be performed in the simulator in a short time and with considerable saving of resources.

\section{Conclusions}

An SMBR computer simulator was built with recent modelling knowledge and a friendly interface. The results given by the simulator are accurate enough to provide the trends and orders of magnitudes of physical quantities needed for the teaching application of the simulated MBR. The practical use of the simulator was evaluated with the development of simulated laboratory work lasting three and a half hours, which gave results that would take more than fifteen months of real-world experiments. It was successfully applied, and achieved the most difficult objectives of enabling the students to analyze the influence of operating parameters on the SMBR functioning and being largely accepted by the students. While this has not been tested, it appears clear that the dynamic model used would permit the training of professionals.

\section{References}

Buer, T., Cumin, J., 2010. MBR module design and operation, Desalination 250, 1073-1077.

Buzatu, P., Lavric, V., 2011. Optimal operating strategies of a Submerged Membrane Bioreactor for wastewater treatment. Chemical and Biochemical Engineering Quarterly 25 (1), 89-103.

Cicek, N., Franco, J.P., Suidan, M.T., Urbain, V., Manem, J., 1999. Characterization and comparison of a membrane bioreactor and a conventional activated-sludge system in the treatment of wastewater containing high molecular weight compounds. Water Environment Research 71, 64-70.

Corominas, L., Rieger, L., Takács, I., Ekama, G., Hauduc, H., Vanrolleghem, P.A., Oehmen, A., Gernaey, K.V., van Loosdrecht, M.C.M., Comeau, Y., 2010. New framework for standardized notation in wastewater treatment modelling. Water Science and Technology 61 (4), 841-857.

Corter, J.E., Esche, S.K., Chassapis, C., Ma, J., Nickerson, J.V., 2011. Process and learning outcomes from remotely operated, simulated, and hands-on student laboratories. Computers \& Education 57, 2054-2067.

De Luca, G., Sacchetti, R., Leoni, E., Zanetti, F., 2013. Removal of indicator bacteriophages from municipal wastewater by a full-scale membrane bioreactor and a conventional activated sludge process: implications to water reuse. Bioresource Technology 129, 526-531.

Drews, A., 2010. Membrane fouling in membrane bioreactors characterisation, contradictions, cause and cures. Journal of Membrane Science 363, 1-28.

El-Naas, M.H., 2011. Teaching water desalination through active learning. Education for Chemical Engineers 6, e97-e102.

Fenu, A., Guglielme, G., Jimenez, J., Spérandio, M., Saroj, D., Lesjean, B., Brepols, C., Thoeye, C., Nopens, I., 2010. Activated sludge model (ASM) based modelling of membrane bioreactor (MBR) processes: a critical review with special regard to MBR specificities. Water Research 44, 4272-4294.

Jimenez, J., Grelier, P., Meinhold, J., Tazi-Pain, A., 2010. Biological modelling of MBR and impact of primary sedimentation. Desalination 250, 562-567.

Kim, M.J., Sankararao, B., Yoo, C.K., 2011. Determination of MBR fouling and chemical cleaning interval using statistical methods applied on dynamic index data. Journal of Membrane Science 375, 345-353.

Koretsky, M.D., Kelly, C., Gummer, E., 2011. Fundamental Research in Engineering Education. Student Learning in Industrially Situated Virtual Laboratories. Chemical Engineering Education (CEE) 45 (3), 219-228.

Korniluk, M., Montusiewicz, A., Piotrowicz, A., Lagód, G., 2008. Simulation of wastewater treatment systems with membrane separation. Proceedings of ECOpole 2 (1), 41-45.

Kraft, M., Mosbach, S., Wagner, W., 2005. Using a web module to teach stochastic modeling. Chemical Engineering Education 39 (3), 244-248.

Li, X.-Y., Wang, X.-M., 2006. Modelling of membrane fouling in a submerged membrane bioreactor. Journal of Membrane Science 278, 151-161.

Lobos, J., Wisniewski, C., Heran, M., Grasmick, A., 2007. Membrane bioreactor performances: effluent quality of continuous and sequencing systems for water reuse. Desalination 204, 39-45.

Lu, S.G., Imai, T., Ukita, M., Sekine, M., Higuchi, T., Fukagawa, M., 2001. A model for membrane bioreactor process based on the concept of formation and degradation of soluble microbial products. Water Research 35, 2038-2048.

Meng, F., Chae, S.R., Drews, A., Kraume, M., Shin, H.S., Yang, F., 2009. Recent advances in membrane bioreactors (MBRs): membrane fouling and membrane material. Water Research 43, 1489-1512.

Menniti, A., Morgenroth, E., 2010. Mechanisms of SMP production in membrane bioreactors: choosing an appropriate mathematical model structure. Water Research 44, 5240-5251.

Perry, G.T., Schnaid, F., 2012. A case study on the design of learning interfaces. Computers \& Education 59, 722-731.

Ramasundaram, V., Grunwald, S., Mangeot, A., Comerford, N.B., Bliss, C.M., 2005. Development of an environmental virtual field laboratory. Computers \& Education 45, 21-34.

Rutten, N., van Joolingen, W.R., van der Veen, J.T., 2012. The learning effects of computer simulations in science education. Computers \& Education 58, 136-153.

Santos, A., Ma, W., Judd, S.J., 2011. Membrane bioreactors: two decades of research and implementation. Desalination 273, 148-154.

Skorzinski, E., Shacham, M., Brauner, N., 2009. A simulation program for modelling pollutant dispersion for educational applications. In: Jeżowski, J., Thullie, J. (Eds.), 19th European Symposium on Computer Aided Process Engineering. Elsevier, Oxford, pp. 1233-1238.

Stephenson, T., Judd, S., Jefferson, B., Brindle, K., 2000. Membrane Bioreactors for Wastewater Treatment. IWA Publishing, London.

van Berkum, J.J.A., de Jong, T., 1991. Instructional environments for simulations. Education \& Computing 6, 305-358.

Van Nieuwenhuijzen, A.F., Evenblij, H., Uijterlinde, C.A., Schulting, F.L., 2008. Review on the state of science on membrane bioreactors for municipal wastewater treatment. Water Science and Technology 57, 979-986.

Zarragoitia, A.G., Schetrite, S., Alliet, M., Jáuregui-Haza, U.J., Albasi, C., 2008. Modelling of submerged membrane bioreactor: conceptual study about link between activated sludge biokinetics, aeration and fouling process. Journal of Membrane Science 325, 612-624. 